\title{
KOMPETENSI DAN PROFESIONALISME PROFESI KEGURUAN
}

\author{
Muhammad Raihan Budiman \\ Email: 2010111110007@mhs.ulm.ac.id \\ Program Studi Pendidikan Sejarah Fakultas Keguruan dan Ilmu Pendidikan \\ Universitas Lambung Mangkurat \\ Banjarmasin
}

\begin{abstract}
Abstrak
Profesi merupakan bidang pekerjaan tertentu yang dinilai telah memenuhi kriteria. Dengan kata lain, tidak semua pekerjaan dapat disebut profesi karena terdapat persyaratanpersyaratan khusus yang harus dipenuhi sehingga suatu bidang pekerjaan dapat disebut sebagai profesi. Salah satu yang sudah memenuhi kriteria adalah profesi guru. Dalam menjalankan profesinya guru memiliki peran,tugas,dan kewajiban. Guru dalam menjalankan profesinya juga harus memiliki profesionalisme dan kompetensi yang harus dimiliki. Ada 4 kompetensi yang harus dimiliki guru agar menjadi guru yang profesional yaitu: kompetensi profesional,kompetensi pedagogik,kompetensi sosial,kompetensi kepribadian. Kompetensi ini menuntut seorang guru untuk menguasai setiap materi yang akan diajarkan,serta cara yang diambil untuk menguasai bidang studi yang diampu. Jika seorang guru tidak ahli dalam bidangnya maka akan berpengaruh buruk pada hasil belajar peserta didik. Jadi 4 kompetensi guru tersebut berperan penting dalam mencapai hasil belajar peserta didik yang maksimal guna untuk memajukan pendidikan di Indonesia.
\end{abstract}

\section{PENDAHULUAN}

Profesi secara etimologi berasal dari kata profession (inggris) yang berasal dari bahasa Latin profesus yang berarti "mampu atau ahli dalam suatu bentuk pekerjaan". Profesi dapat diartikan sebagai suatu pekerjaan atau jabatan yang menuntut keahlian, yang didapat melalui pendidikan dan latihan tertentu, menurut persyaratan khusus memiliki tanggung jawab dan kode etik tertentu. Pekerjaan yang bersifat profesional berbeda dengan pekerjaan lainnya karena suatu profesi memerlukan kemampuan dan keahlian khusus dalam 
melaksanakan profesinya. Profesi juga diartikan sebagai suatu jabatan atau pekerjaan tertentu yang mensyaratkan pengetahuan dan keterampilan khusus yang diperoleh dari pendidikan akademis yang intensif. Jadi profesi adalah suatu pekerjaan atau jabatan yang menuntut keahlian tertentu. Artinya suatu pekerjaan atau jabatan yang disebut profesi tidak dapat dipegang oleh sembarang orang, tetapi memerlukan persiapan melalui pendidikan dan pelatihan secara khusus. (Susanto, 2020:13).

Berdasarkan pada beberapa kriteria tersebut, maka profesi merupakan bidang pekerjaan tertentu yang dinilai telah memenuhi kriteria. Dengan kata lain, tidak semua pekerjaan dapat disebut profesi karena terdapat persyaratan-persyaratan khusus yang harus dipenuhi sehingga suatu bidang pekerjaan dapat disebut sebagai profesi. Profesi pada hakikatnya adalah suatu pernyatan atau suatu janji terbuka yang menyatakan bahwa seseorang itu mengabdikan dirinya pada suatu jabatan atau pelayanan karena orang tersebut merasa terpanggil untuk menjabat pekerjaan itu. Istilah profesi merupakan simbol dari suatu pekerjaan itu sendiri, profesi mengajar adalah suatu jabatan yang mempunyai kekhususan. Kekhususan itu merupakan kelengkapan mengajar atau keterampilan yang menggambarkan bahwa seseorang melakukan tugas mengajar, yaitu membimbing manusia. (Susanto, 2020:14).

Berdasarkan pengertian di atas, meskipun profesi adalah karir seumur hidup dan ada konsekuensi ekonomis atas pekerjaan di bidang profesi tersebut, akan tetapi fokus utamya terletak pada pengabdian dan tanggungjawab moril sesuai bidang keilmuan profesi. Dengan demikian tanggungjawab insan profesi bukan hanya kepada atasan atau pemerintah, melainkan juga kepada bidang keilmuan dan kemanusiaan. Tanggung jawab tersebut juga menjadi pembeda antara profesi dengan bidang pekerjaan lain yang bukan profesi. (Susanto, 2020:14).

Menurut Susanto (2020:14-17) secara umum syarat suatu pekerjaan untuk dapat digolongkan menjadi suatu profesi yaitu:

1) Memiliki spesialisasi ilmu, setiap profesi dibangun berdasarkan kekhususan keilmuan, sehingga orang yang masuk dalam suatu bidang profesi haruslah orang yang memiliki latar belakang keilmuan yang sesuai. Hal ini menjelaskan bahwa tidak sembarang orang dapat bekerja 
di suatu bidang profesi jika tidak memiliki latar belakang keilmuan yang relevan.

2) Memiliki kode etik dalam menjalankan profesi, kode etik merupakan pedoman etik atau pedoman moral bagi anggota profesi dalam menjalankan tugasnya. Kode etik profesi diperlukan untuk menjaga martabat dan menjadi pedoman bagi insan profesi dalam menjalankan profesinya.

3) Memiliki organisasi profesi, organisasi merupakan wadah perjuangan dan perkumpulan insan profesi. Organisasi profesi juga berfungsi sebagai wadah untuk pengembangan profesi melalui sharing inovasi dan komunikasi suatu profesi. Melalui organisasi ini insan profesi akan memiliki kesepakatan yang sama dalam menjalankan profesinya dan memiliki kemampuan untuk merespon berbagai kebijakan dan tantangan terkait profesi. Organisasi profesi dapat menjadi simbol kuatnya suatu profesi di tengah masyarakat.

4) Diakui masyarakat, suatu profesi harus mendapat pengakuan masyarakat. Pengakuan ini diperoleh jika profesi tersebut telah terbukti memiliki peran sesuai bidangnya. Pengakuan masyarakat merupakan bentuk legimitasi terhadap keberadaan dan peran suatu profesi.

5) Sebagai panggilan hidup, profesi merupakan karir sepanjang hayat, dengan demikian profesi akan mendarah daging bagi orang yang menjalankannya. Bekerja di bidang profesi sangat berbeda dengan bekerja di bidang lain, bekerja di bidang profesi mengharuskan seseorang untuk mengabdikan diri secara penuh dan terus mendalami keilmuan bidang profesi tersebut, sehingga semakin lama seseorang berkecimpung dalam suatu bidang profesi maka akan semakin ahli dalam bidang tersebut.

6) Dilengkapi kecakapan diagnostik, sebagai bidang pekerjaan yang memerlukan pengambilan keputusan otonom dari insan profesi, maka orang yang bekerja di bidang profesi diharuskan memiliki kemampuan 
diagnostik. Kemampuan diagnostik adalah kemampuan memperkirakan penyebab dan atau akibat berdasarkan gejala atau ciri-ciri tertentu, menganalisis, serta kemampuan untuk menentukan tindakan yang tepat untuk menangani atau menyelesaikan permasalahan.

7) Mempunyai klien yang jelas, karena profesi merupakan pekerjaan di bidang jasa, maka setiap profesi pasti memiliki klien yang jelas. Dokter memiliki klien pasien, pengacara memiliki klien orang yang berperkara hukum, guru memiliki klien murid. Kejelasan klien ini yang menunjukkan bahwa bidang profesi adalah pekerjaan yang sangat spesifik dan berbeda antara satu profesi dengan profesi lainnya, sehingga seseorang tidak dapat beralih profesi tanpa latar belakang pendidikan dan keahlian yang relevan.

Berdasarkan UU RI No.14 tahun 2005 tentang Guru dan Dosen Pasal 1 (dalam Susanto, 2020:16), Guru adalah pendidik profesional dengan tugas utama mendidik, mengajar, membimbing, mengarahkan, melatih, menilai, dan mengevaluasi peserta didik pada pendidikan anak usia dini jalur pendidikan formal, pendidikan dasar, dan pendidikan menengah. Dosen adalah pendidik profesional dan ilmuan dengan tugas utama mentransformasikan, mengembangkan, dan menyebarluaskan ilmu pengetahuan, teknologi, dan seni melalui pendidikan, penelitian, dan pengabdian kepada masyarakat.

Guru adalah pendidik, yaitu orang dewasa yang bertanggung jawab memberi bimbingan atau bantuan kepada anak didik dalam perkembangan jasmani dan rohaninya agar mencapai kedewasaannya, mampu berdiri sendiri dapat melaksanakan tugasnya sebagai makhluk Allah khalifah di muka bumi, sebagai makhluk sosial dan individu yang sanggup berdiri sendiri. (Susanto, 2020:16).

Guru merupakan suatu profesi, yang berarti suatu jabatan yang memerlukan keahlian khusus sebagai guru dan tidak dapat dilakukan oleh sembarang orang diluar bidang pendidikan. Walaupun pada kenyataannya masih terdapat guru yang tidak memiliki latar belakang pendidikan bidang keguruan. Menurut Susanto (2020:17-18) Seorang guru berkaitan dengan aktivitas profesinya diharuskan mengetahui dan dapat menerapkan 
beberapa prinsip mengajar agar ia dapat melaksanakan tugasnya secara profesional, yaitu sebagai berikut.

1) Guru harus dapat membangkitkan perhatian perserta didik pada materi pelajaran yang diberikan serta dapat menggunakan berbagai media dan sumber belajar yang bervariasi.

2) Guru harus dapat membangkitkan minat peserta didik untuk aktif dalam bepikir serta mencari dan menemukan sendiri pengetahuan.

3) Guru harus dapat membuat urutan (sequence) dalam pemberian pelajaran dan penyesuaiannya dengan usia dan tahap tugas perkembangan peseta didik.

4) Guru perlu menghubungkan pelajaran yang akan diberikan dengan pengetahuan yang telah dimiliki peserta didik (kegiatan apersepsi), agar peserta didik menjadi mudah dalam memahami pelajaran yang diterimanya.

5) Sesuai dengan prinsip repetisi dalam proses pembelajaran, diharapkan guru dapat menjelaskan unit pelajaran secara berulang-ulang hingga tanggapan peserta didik menjadi jelas.

6) Guru wajib memperhatikan dan memikirkan korelasi atau hubungan antara mata pelajaran atau praktik nyata dalam kehidupan sehari-hari.

7) Guru harus tetap menjaga konsentrasi belajar para peserta didik dengan cara memberikan kesempatan berupa pengalaman secara langsung, mengamati atau meneliti, dan menyimpulkan pengetahuan yang didapatkanya.

8) Guru harus mengembangkan sikap peserta didik dalam membina hubungan sosial,baik dalam kelas maupun diluar kelas.

9) Guru harus menyelidiki dan mendalami perbedaan peserta secara individual agar dapat melayani siswa sesuai dengan perbedaannya tersebut.

Guru dapat melaksanakan evaluasi yang efektif serta menggunakan hasilnya untuk mengetahui peserta dan kemajuan siswa serta dapat melakukan perbaikan dan pengembangan.

Seiring dengan kemajuan teknologi informasi yang telah demikian pesat, guru tidak lagi hanya bertindak sebagai penyaji informasi, tetapi juga harus mampu bertindak sebagai fasilitator, motivator, dan pembimbingan yang lebih banyak memberikan kesempatan 
kepada peserta didik untuk mencari dan mengolah sendiri informasi. Dengan demikian, keahlian guru harus terus dikembangkan dan tidak hanya terbatas pada penguasaan prinsip mengajar seperti telah diuraikan.

\section{PERAN GURU SEBAGAI SEBUAH PROFESI}

Guru merupakan profesi tertua didunia seumur dengan keberadaan manusia. Bukankah ibu dan keluarga merupakan guru yang pertama dalam kehidupan. Tidak mengherankan apabila di dalam masyarakat, profesi guru dianggap dapat dilakukan oleh semua orang. Sehingga sekarang ini, pertanyaan yang masih muncul berkaitan dengan profesi guru yaitu "Apakah pekerjaan guru itu suatu profesi?" Pertanyaan ini muncul karena disatu sisi guru adalah pendidik, sehingga banyak yang beranggapan setiap orang dapat dan berhak mendidik (Susanto, 2020: 20). Disisi lain ada sebagian orang yang menjadi guru tanpa melalui jalur pendidikan guru tetapi dapat melaksanakan tugasnya sama atau lebih baik dari pada mereka yang berlatar belakang guru.

Guru adalah posisi yang strategis bagi pemberdayaan dan pembelajaran suatu bangsa yang tidak mungkin digantikan oleh unsur manapun dalam kehidupan sebuah bangsa sejak dahulu. Semakin signifikannya keberadaan guru melaksanakan peran dan tugasnya semakin terjamin terciptanya kehandalan dan terbinanya kesiapan seseorang. Dengan kata lain potret manusia yang akan datang tercermin dari potret guru di masa sekarang dan gerak maju dinamika kehidupan sangat bergantung dari "citra" guru di tengah-tengah masyarakat. (Susanto, 2020:20).

Guru sudah memenuhi syarat sebagai profesi sebagaimana dikutif Soetjipto dan Kosasi (dalam Susanto 2020:17), antara lain yaitu:

a) Adanya komitmen dari para guru bahwa jabatan itu mengharuskan pengikutnya menjunjung tinggi martabat kemanusiaan lebih dari pada mencari keuntungan diri sendiri.

b) Suatu profesi mensyaratkan orangnya mengikuti persiapan profesional dalam jangka waktu tertentu.

c) Harus selalu menambah pengetahuan agar terus menerus berkembang dalam jabatannya. 
d) Memiliki kode etik jabatan.

e) Memiliki kemampuan intelektual menjawab masalah-masalah yang dihadapi.

f) Selalu ingin belajar terus-menerus mengenai bidang keahlian yang ditekuni.

g) Menjadi anggota dari suatu organisasi profesi.

h) Jabatan itu dipandang sebagai suatu karir hidup.

Masyarakat mana yang tidak membutuhkan profesi guru. Tidak dapat dipungkiri bahwa masyarakat tanpa profesi guru tidak mungkin tercipta suatu generasi unggul, kreatif dan cerdas. (Susanto, 2020:21).

Guru merupakan satu di antara profesi di bidang pendidikan. Dalam UndangUndang No. 14 Tahun 2005 (dalam Susanto, 2020:37), dikatakan guru adalah pendidik profesional dengan tugas utama mendidik, mengajar, membimbing, mengarahkan, melatih, menilai, dan mengevaluasi peserta didik pada pendidikan anak usia dini jalur pendidikan formal, pendidikan dasar, dan pendidikan menengah. Guru dapat diartikan sebagai orang yang tugasnya terkait dengan upaya mencerdaskan kehidupan bangsa dalam semua aspeknya, baik spiritual dan emosional, intelektual, fisikal, maupun aspek lainnya.

Dalam Undang-Undang No.14 Tahun 2005, peran atau tugas utama guru adalah mendidik, mengajar, membimbing, mengarahkan, melatih, menilai, dan mengevaluasi peserta didik pada pendidikan anak usia dini jalur pendidikan formal, pendidikan dasar, dan pendidikan menengah. (Shabir, 2015:221). Jika diidentifikasi dari filosofi pendidikan Indonesia yang dicetuskan Ki Hadjar Dewantara "ing ngarso sung tulodo, ing madya mangun karso, tutwuri handayani” maka peran guru adalah sebagai:

a) Role model (ing ngarso sung tulodo), memberikan teladan kepada siswa karena fungsi guru menjadi pemimpin siswa dalam kegiatan pembelajaran.

b) Motor penggerak (ing madya mangun karso), guru harus menjadi penggerak inovasi dalam proses pendidikan dan penggerak peradaban dengan cara mengarahkan siswa untuk melakukan yang benar. 
c) Motivator (tutwuri handayani), mampu memberikan dorongan semangat kepada siswa untuk mengadapi setiap persoalan dan mempelajari nilai-nilai kehidupan. (Susanto, 2020 :38-39)

Dalam menjalankan tugas dan profesinya, guru memiliki hak dan kewajiban yang harus dilaksanakan dan diperhatikan. Hak guru berarti suatu yang harus didapatkan olehnya setelah ia melaksanakan sejumlah kewajibannya sebagai guru. Kewajiban guru adalah sesuatu yang harus patut dilaksanakan oleh guru dalam menjalankan profesinya. Hak dan kewajiban guru sebagai pendidik diatur di semua peraturan perundang-undangan yang berkaitan dengan pendidikan. Dalam UU No. 14 Tahun 2005 tentang guru dan dosen pada bagian kedua mengenai hak dan kewajiban pada pasal 14, adapun hak yang dimiliki oleh seorang guru sebagai berikut:

a. Memperoleh penghasilan di atas kebutuhan hidup minimum dan jaminan kesejahteraan sosial.

b. Mendapatkan promosi dan penghargaan sesuai dengan tugas dan prestasi kerja.

c. Memperoleh perlindungan dalam melaksanakan tugas dan hak atas kekayaan intelektual.

d. Memperoleh kesempatan untuk meningkatkan kompetensi.

e. Memperoleh dan memanfaatkan sarana dan prasarana pembelajaran untuk menunjang kelancaran tugas keprofesionalan.

f. Memiliki kebebasan dalam memberikan penilaian dan ikut menentukan kelulusan, penghargaan, dan atau sanksi kepada peserta didik sesuai dengan kaidah pendidikan, kode etik guru, dan peraturan perundang-undangan.

g. Memperoleh rasa aman dan jaminan keselamatan dalam melaksanakan tugas.

h. Memiliki kebebasan untuk berserikat dalam organisasi profesi.

i. Memiliki kesempatan untuk berperan dalam penentuan kebijakan pendidikan.

j. Memperoleh kesempatan untuk mengembangkan dan meningkatkan kualifikasi akademik dan kompetensi. 
k. Memperoleh pelatihan dan pengembangan profesi dalam bidangnya. (Susanto, 2020:44-45).

Setelah mengetahui hak guru seperti diatas, guru juga memiliki kewajiban dalam melaksanakan tugas keprofesionalan dalam UU No. 14 tahun 2005 tentang guru dan dosen, pada pasal 20 (dalam Susanto, 2020:48) maka guru berkewajiban sebagai berikut:

a. Merencanakan pembelajaran, melaksanakan proses pembelajaran yang bermutu, serta menilai dan mengevaluasi hasil pembelajaran.

b. Mengembangkan dan meningkatkan kualifikasi akademik dan kompetensi secara berkelanjutan sejalan dengan perkembangan ilmu pengetahuan, teknologi dan seni.

c. Bertindak objektif dan tidak diskriminatif atas dasar pertimbangan jenis kelamin, agama, suku, ras, dan kondisi fisik tertentu, atau latar belakang keluarga, dan status sosial ekonomi peserta didik dalam pembelajaran

d. Menjunjung tinggi peraturan perundang undangan, hukum dan kode etik guru, serta nilai nilai agama dan etika.

e. Memelihara dan memupuk persatuan dan kesatuan bangsa.

Menurut Roestiyah N.K (dalam Susanto, 2020:48) bahwa guru dalam mendidik anak didik bertugas untuk :

a. Menyerahkan kebudayaan kepada anak didik berupa kepandaian, kecakapan, dan pengalaman-pengalaman.

b. Membentuk kepribadian anak yang harmonis, sesuai cita-cita dan dasar negara kita pancasila.

c. Menyiapkan anak menjadi warga negara yang baik sesuai undang-undang pendidikan.

d. Sebagai perantara dalam belajar. Didalam proses belajar guru hanya sebagai perantara/medium, anak harus berusaha sendiri mendapatkan suatu pengertian, sehingga timbul perubahan dalam pengetahuan, tinggkah laku, dan sikap.

e. Guru adalah sebagai pembimbing, untuk membawa anak didik ke arah kedewasaan, tidak dapat membentuk anak menurut sekehendaknya. 
f. Guru sebagai penghubung antar sekolah dan masyarakat. Anak nantinya akan hidup dan bekerja, serta mengabdikan diri dalam masyarakat, dengan demikian anak harus dilatih dan dibiasakan disekolah dibwah pengawasan guru.

g. Sebagai penegak disiplin, guru menjadi contoh dalam segala hal, tata tertib dapat berjalan bila guru dapat menjalani terlebih dahulu.

h. Guru sebagai administrator dan manajer. Disamping mendidik, seorang guru harus dapat mengerjakan urusan tata usaha seperti membuat buku kas, daftar induk, rapor, daftar gaji dan sebagainya, serta dapat mengkoordinasi segal pekerjaan di sekolah secara demokratis, sehingga suasana pekerjaan penuh dengan rasa kekeluargaaan.

i. Pekerjaan guru sebagai suatu profesi.

j. Guru sebagai perencana kurikulum. Guru menghadapin anak-anak setiap hari, gurulah yang paling tau kebutuhan anak-anak dan masyarakat sekitar, maka dalam penyusunan kurikulum, kebutuhan ini tidak boleh di tinggalkan.

k. Guru sebagai pemimpin (guidance worker). Guru mempunyai kesepatan dan tanggung jawab dalam banyak situasi untuk membimbing anak kearah pemecah soal, membentuk keputusan, dan menghadapkan anak-anak pada problem.

1. Guru sebagai seponsor dalam kegiatan anak-anak. Guru harus turut aktif dalam segala aktivitas anak, misalnya ekstrakurikuler membentuk kelompok belajar dan sebagainya.

Dengan poin-poin yang telah disebutkan diatas maka alangkah lebih baiknya kita dapat menghargai guru dengan baik lagi, karna yang kita pahami bahwa banyak nya tugas guru yang dilakukan yang mana bukan hanya untuk mendidik tetapi juga berbagai macam hal lainnya.

\section{GURU INDONESIA DAN TANTANGAN PROFESIONALISME}

Kompetensi profesional berasal dari dua kata yaitu kompetensi dan profesional. Pengertian dasar kompetensi (competency) adalah kemampuan atau kecakapan. Dalam 
Kamus Besar Bahasa Indonesia kompetensi berarti kewenangan/kekuasaan untuk menentukan (memutuskan sesuatu). Keputusan Menteri Pendidikan Nasional No. 045/4/2002 menyebutkan kompetensi sebagai seperangkat tindakan cerdas dan penuh tanggungjawab dalam melaksanakan tugas-tugas sesuai dengan pekerjaan tertentu. Sedangkan profesional menunjuk pada dua hal, pertama orang yang menyandang suatu profesi, kedua penampilan seseorang dalam melakukan pekerjaan yang sesuai dengan profesinya. (Susanto, 2020:62-63).

Jadi dari berbagai pengertian di atas maka yang dimaksud dengan kompetensi profesional guru ialah kemampuan dan kewenangan guru dalam menjalankan profesi keguruannya, artinya guru yang piawai dalam melaksanakan profesinya dapat disebut sebagai guru yang kompeten dan profesional. Kompetensi profesional merupakan pekerjaan yang hanya dapat di lakukan oleh seorang yang mempunyai kualifikasi akademik, kompetensi dan sertifikat pendidik sesuai dengan persyaratan untuk setiap jenis dan jenjang pendidikan tertentu. (Susanto, 2020:63).

Kompetensi profesional merupakan kemampuan dasar yang harus dimiliki oleh guru. Ada beberapa pandangan ahli tentang kompetensi profesional guru. Menurut Cooper (dalam Susanto, 2020:63) terbagi kedalam 4 komponen kompetensi dasar, yakni:

a. Mempunyai pengetahuan tentang belajar dan tingkah laku manusia.

b. Mempunyai pengetahuan dan menguasai bidang studi yang dibinanya.

c. Mempunyai sikap yang tepat tentang diri sendiri, sekolah, teman sejawat dan bidang studi yang dibinanya.

d. Mempunyai keterampilan dalam tekhnik mengajar.

Kompetensi profesional merupakan kemampuan dasar yang harus dimiliki oleh guru,karena dengan kompetensi profesional guru diharapkan dapat menghasilkan peserta didik yang mampu memahami materi secara keseluruhan dan bahkan dapat meningkatkan keingin tahu an pada peserta didik,sehingga peserta didik memiliki keinginan untuk terus berkembang.

Menjadi guru harus ahli dalam bidangnya. Sehingga kompetensi profesional menuntut seorang guru untuk menguasai setiap materi yang akan diajarkan,serta cara yang diambil untuk menguasai bidang studi yang diampu. Jika seorang guru tidak ahli dalam bidangnya 
maka akan berpengaruh buruk pada hasil belajar peserta didik. Jadi kompetensi profesional guru berperan penting dalam mencapai hasil belajar peserta didik yang maksimal guna untuk memajukan pendidikan di Indonesia.

Untuk menjadi guru yang profesional harus memiliki 4 kompetensi guru profesional yaitu: kompetensi pedagogik, kepribadian, profesional, dan sosial. Menurut Saragih (2008:23) dalam hal keterampilan, seorang guru harus menguasai keterampilan mengajar, yaitu: membuka dan menutup pelajaran, bertanya, memberi penguatan, dan mengadakan variasi mengajar. Dalam proses belajar-mengajar, guru memegang peran sebagai sutradara sekaligus aktor dan merupakan faktor yang sangat dominan dalam menentukan keberhasilan proses belajar-mengajar di kelas.

Sudah dibahas diatas mengenai kompetensi profesional yang harus dimiliki guru,selanjutnya akan kita bahas mengenai kompetensi pedagogik. Menurut Suardi (dalam Susanto, 2020:67) Pedagogik adalah teori mendidik yang mempersoalkan apa dan bagaimana mendidik sebaik-baiknya. Sedangkan menurut pengertian Yunani, pedagogik adalah ilmu menuntun anak yang membicarakan masalah atau persoalan-persoalan dalam pendidikan dan kegiatan-kegiatan mendidik, antara lain seperti tujuan pendidikan, alat pendidikan, cara melaksanakan pendidikan, anak didik, pendidik dan sebagainya. Oleh sebab itu, pedagogik dipandang sebagai proses atau aktivitas yang bertujuan agar tingkah laku manusia mengalami perubahan (Susanto, 2020:67).

Menurut Badan Standar Nasional Pendidikan (dalam Susanto, 2020:71-74) dalam Undang-Undang RI Nomor 14 Tahun 2005 tentang Guru dan Dosen, yang dimaksud dengan kompetensi pedagogik adalah kemampuan dalam pengelolaan peserta didik yang meliputi: pemahaman wawasan atau landasan kependidikan, pemahaman tentang peserta didik, perkembangan kurikulum atau silabus; perancangan pembelajaran, pelaksanaan pembelajaran yang mendidik dan dialogis, evaluasi hasil belajar, pengembangan peserta didik untuk mengaktualisasikan berbagai potensi yang dimilikinya. Dari aspek legal formal kompetensi pedagogik guru berdasarkan Permendiknas No.16 tahun 2007 (dalam Susanto, 2020:71-74), adalah sebagai berikut: 
a. Menguasai karakteristik peserta didik dari aspek fisik, moral, spiritual, osial, kultural, emosional, dan intelektual.

b. Menguasai teori belajar dan prinsip-prinsip pembelajaran yang mendidik.

c. Mengembangkan kurikulum yang terkait dengan mata pelajaran yang diampu.

d. Menyelenggarakan pembelajaran yang mendidik.

e. Memanfaatkan teknologi informasi dan komunikasi untuk kepentingan pembelajaran.

f. Memfasilitasi pengembangan potensi peserta didik untuk mengaktualisasikan berbagai potensi yang dimiliki.

g. Berkomunikasi secara efektif, empatik, dan santun dengan peserta didik.

h. Menyelenggarakan penilaian dan evaluasi proses dan hasil belajar.

i. Memanfaatkan hasil penilaian dan evaluasi untuk kepentingan pembelajaran.

j. Melakukan tindakan reflektif untuk peningkatan kualitas pembelajaran.

Jadi apabila guru menguasai kompetensi pedagogik ini tentu hasil belajar pun akan memuaskan sebaliknya apabila guru tidak menguasai kompetensi ini hasil belajar pun tentu akan mengecewakan. Disarankan untuk para guru agar dapat meningkatkan kompetensi pedagogiknya dalam upaya peningkatan kualitas guru, dan untuk memotivasi pencapaian hasil belajar siswa yang memuaskan.

Selain kompetensi profesional dan kompetensi pedagogik,ada kompetensi sosial yang harus dimiliki seorang guru. Menurut Satori dkk (dalam Susanto, 2020 74-75) Kompetensi sosial guru merupakan kemampuan guru untuk memahami dirinya sebagai bagian dari masyarakat dan mampu mengembangkan tugas sebagai anggota masyarakat dan warga negara. Dalam hal ini seorang guru diharuskan untuk bisa memahami dirinya sebagai anggota masyarakat dan bisa beradaptasi di tengah kehidupan masyarakat dengan memahami dan menerapkan nilai dan norma yang berlaku di masyarakat karena guru merupakan bagian dari masyarakat. Selain itu, dalam memenuhi tanggung jawab sebagai pengajar, guru harus bisa mencerdaskan masyarakat sebagaimana diatur dalam pembukaan undang-undang dasar negara republik Indonesia pada alinea ke empat. 
Menurut Jejen Musfah (dalam Susanto, 2020:75) pengertian kompetensi sosial guru merupakan kemampuan pendidik sebagai bagian dari masyarakat untuk : a) berkomunikasi lisan dan tertulis; b) menggunakan teknologi komunikasi dan informasi secara fungsional; c) bergaul secara efektif dengan peserta didik, sesama pendidik, tenaga kependidikan, orang tua atau wali peserta didik; dan d) bergaul secara santun dengan masyarakat sekitar.

Selain pendapat ahli diatas, menurut Permendiknas No.16 tahun 2007 (dalam Susanto, 2020:78-80),komponen kompetensi sosial guru yaitu:

a. Bersikap inklusif,bertindak objektif,serta tidak diskriminatif karena pertimbangan jenis kelamin,agama,ras,kondisi fisik,latar belakang, keluarga,dan status sosial ekonomi.

b. Berkomunikasi secara efektif,empatik,dan santun dengan sesama pendidik,tenaga kependidikan,orang tua,dan masyarakat.

c. Beradaptasi di tempat bertugas di seluruh wilayah Republik Indonesia yang memiliki keragaman sosial budaya.

d. Berkomunikasi dengan komunitas profesi sendiri dan profesi lain secara lisan dan tulisan atau bentuk lain.

Selain 3 jenis kompetensi yang sudah dijelaskan diatas ada kompetensi kepribadian yang harus dimiliki guru. Menurut penjelasan Peraturan Pemerintah No 19 Tahun 2005 (dalam Susanto, 2020:80) tentang Standar Nasional Pendidikan disebutkan bahwa kompetensi kepribadian guru yaitu kemampuan kepribadian yang: 1) mantap; 2) stabil; 3) dewasa; 4) arif dan bijaksana; 5) berwibawa; 6) berakhlak mulia; 7) menjadi teladan bagi peserta didik dan masyarakat; 8) mengevaluasi kinerja sendiri; dan 9) mengembangkan diri secara berkelanjutan.

Menurut Permendiknas No. 16 Tahun 2007 (dalam Susanto, 2020:80-81) tentang Kualifikasi dan Kompetensi Guru menjelaskan kompetensi kepribadian untuk guru kelas dan guru mata pelajaran, pada semua jenjang pendidikan dasar dan menengah, sebagai berikut:

a. Bertindak sesuai dengan norma agama, hukum, sosial, dan kebudayaan nasional Indonesia, mencakup: a) menghargai peserta didik tanpa membedakan keyakinan yang dianut, suku, adat-istiadat, daerah asal, dan gender; dan b) 
bersikap sesuai dengan norma agama yang dianut, hukum dan sosial yang berlaku dalam masyarakat, dan kebudayaan nasional Indonesia yang beragam.

b. Menampilkan diri sebagai pribadi yang jujur, berakhlak mulia, dan teladan bagi peserta didik dan masyarakat, mencakup: a) berperilaku jujur, tegas, dan manusiawi; b) berperilaku yang mencerminkan ketakwaan dan akhlak mulia; dan c) berperilaku yang dapat diteladani oleh peserta didik dan anggota masyarakat di sekitarnya.

c. Menampilkan diri sebagai pribadi yang mantap, stabil, dewasa, arif, dan berwibawa, mencakup: a) menampilkan diri sebagai pribadi yang mantap dan stabil; dan b) menampilkan diri sebagai pribadi yang dewasa, arif, dan berwibawa.

d. Menunjukkan etos kerja, tanggung jawab yang tinggi, rasa bangga menjadi guru, dan rasa percaya diri, mencakup: a) menunjukkan etos kerja dan tanggung jawab yang tinggi; b) bangga menjadi guru dan percaya pada diri sendiri; dan c) bekerja mandiri secara profesional.

e. Menjunjung tinggi kode etik profesi guru, mencakup: a) memahami kode etik profesi guru; b) menerapkan kode etik profesi guru; dan c) berperilaku sesuai dengan kode etik guru.

Melatih kepribadian guru merupakan salah satu hal yang tetap harus dikembangkan dan berkelanjutan. Pembinaan dan pengembangan profesi guru meliputi pembinaan kompetensi profesional,pedagogik,sosial dan kepribadian. Pelatihan dan pengembangan profesi guru dimaksud antara lain dilakukan melalui pendidikan dan pelatihan dalam jabatan. (Susanto, 2020:92).

\section{SIMPULAN}

Profesi adalah suatu pekerjaan atau jabatan yang menuntut keahlian tertentu. Artinya suatu pekerjaan atau jabatan yang disebut profesi tidak dapat dipegang oleh sembarang orang, tetapi memerlukan persiapan melalui pendidikan dan pelatihan secara khusus. Guru sudah memenuhi syarat sebagai suatu profesi yang mana salah satu syaratnya adalah memiliki spesialisasi ilmu. Guru merupakan suatu profesi, yang berarti suatu jabatan yang memerlukan keahlian khusus sebagai guru dan tidak dapat dilakukan oleh sembarang 
orang diluar bidang pendidikan. Walaupun pada kenyataannya masih terdapat guru yang tidak memiliki latar belakang pendidikan bidang keguruan. Seorang guru berkaitan dengan aktivitas profesinya diharuskan mengetahui dan dapat menerapkan beberapa prinsip mengajar agar ia dapat melaksanakan tugasnya secara profesional.

Dalam menjalankan tugas dan profesinya, guru memiliki hak dan kewajiban yang harus dilaksanakan dan diperhatikan. Hak dan kewajiban guru sebagai pendidik diatur di semua peraturan perundang-undangan yang berkaitan dengan pendidikan yaitu dalam UU No. 14 Tahun 2005 tentang guru dan dosen pada bagian kedua mengenai hak dan kewajiban pada pasal 14. Jika diidentifikasi dari filosofi pendidikan Indonesia yang dicetuskan Ki Hadjar Dewantara "ing ngarso sung tulodo, ing madya mangun karso, tutwuri handayani" maka peran guru adalah sebagai role model,motor penggerak,dan motivator.

Menjadi guru harus ahli dalam bidangnya. Sehingga kompetensi profesional menuntut seorang guru untuk menguasai setiap materi yang akan diajarkan,serta cara yang diambil untuk menguasai bidang studi yang diampu. Jika seorang guru tidak ahli dalam bidangnya maka akan berpengaruh buruk pada hasil belajar peserta didik. Jadi kompetensi profesional guru berperan penting dalam mencapai hasil belajar peserta didik yang maksimal guna untuk memajukan lagi pendidikan di Indonesia. Dan untuk menjadi guru yang profesional ada 4 kompetensi yang harus dimiliki seorang guru yaitu kompetensi profesional,kompetensi pedagogik,kompetensi sosial, dan kompetensi kepribadian.

\section{REFERENSI}

Efendi, I., Prawitasari, M., \& Susanto, H. (2021). Implementasi Penilaian Pembelajaran Pada Kurikulum 2013 Mata Pelajaran Sejarah. Prabayaksa: Journal of History Education, 1(1), 21-25.

Susanto, H. (2020). Profesi Keguruan. Banjarmasin: FKIP Universitas Lambung Mangkurat.

Susanto, H., \& Akmal, H. (2018). Efektivitas Penggunaan Aplikasi Pembelajaran Berbasis Mobile Smartphone Sebagai Media Pengenalan Sejarah Lokal Masa Revolusi Fisik Di Kalimantan Selatan Pada Siswa Sekolah Menengah Atas. HISTORIA: Jurnal Program Studi Pendidikan Sejarah, 6(2), 197-206. 
Susanto, H., Irmawati, I., Akmal, H., \& Abbas, E. W. (2021). Media Film Dokumenter Masuknya Islam Ke Nusantara dan Pengaruhnya Terhadap Keterampilan Berpikir Kritis Siswa. HISTORIA: Jurnal Program Studi Pendidikan Sejarah, 9(1).

Syaharuddin, S., \& Susanto, H. (2019). Sejarah Pendidikan Indonesia (Era Pra Kolonialisme Nusantara sampai Reformasi). Banjarmasin: FKIP Universitas Lambung Mangkurat.

Shabir U,M.(2015). KEDUDUKAN GURU SEBAGAI PENDIDIK: (Tugas dan Tanggung Jawab, Hak dan Kewajiban, dan Kompetensi Guru). Jurnal AULADUNA, 2(2),221.

Saragih,Hasan A.(2008). KOMPETENSI MINIMAL SEORANG GURU DALAM MENGAJAR. Jurnal TABULARASA PPS UNIMED,5(1),23. 